\title{
Zinc-Doped Titania Embedded on the Surface of Zirconia: A Potential Visible-Responsive Photocatalyst Material
}

\author{
Azizia Alifi, Rian Kurniawan, and Akhmad Syoufian* \\ Department of chemistry, Faculty of Mathematics and Natural Sciences, Universitas Gadjah Mada, \\ Sekip Utara, Yogyakarta 55281, Indonesia
}

* Corresponding author:

email:akhmadsyoufian@ugm.ac.id

Received: November 5, 2019

Accepted: February 4, 2020

DOI: $10.22146 / \mathrm{ijc} .51172$

\begin{abstract}
The preparation and characterization of zirconia-supported titania with a zinc dopant had been studied. Zinc-doped titania was grown on the surface of zirconia by the sol-gel method. Various zinc contents and calcination temperatures were applied to investigate the zinc doping effect and crystal structure of the zirconia-titania composite. $X$-ray diffraction method, Fourier-transform infrared spectroscopy, and UV-Vis reflectance spectroscopy were performed to characterize the composite. The morphology of the composite was observed by using a scanning electron microscope, and its composition was analyzed by using energy dispersive spectroscopy. Among various zinc dopant contents and calcination temperatures investigated, doping with 5\% zinc ( $\mathrm{Zn}$ wt./Ti wt.) at $900{ }^{\circ} \mathrm{C}$ calcination shows the best result in response to visible light with a bandgap of $2.87 \mathrm{eV}$ and absorption edge wavelength of $432.61 \mathrm{~nm}$.
\end{abstract}

Keywords: titania; zinc; zirconia; sol-gel; doping

\section{- INTRODUCTION}

$\mathrm{TiO}_{2}$ has a high photoactivity under ultraviolet light irradiation because of its large bandgap $(3.25 \mathrm{eV}$ for anatase). However, solar light consists of $5 \%$ UV light (300-400 $\mathrm{nm})$ and $43 \%$ visible light (400-700 $\mathrm{nm})$. That is, the UV light only occupies a small portion of the sunlight, and a large part of solar energy cannot be utilized. $\mathrm{TiO}_{2}$ also shows a higher recombination rate of photogenerated electrons and holes [1]. The photocatalytic performance of $\mathrm{TiO}_{2}$ can be effectively improved through transition metal doping. Among other metals, $\mathrm{Zn}$ has drawn considerable attention because of its superior doping effect on the improvement of $\mathrm{TiO}_{2}$ photocatalytic performance under visible irradiation [2-3]. Seabra et al. reported that the inhibition of anatase-to-rutile transformation and the increment of specific surface area are responsible for the improvement of $\mathrm{TiO}_{2}$ photocatalytic performance under visible irradiation by zinc doping [2].

Titania has also been combined with other semiconductors such as zirconium dioxide $\left(\mathrm{ZrO}_{2}\right) \cdot \mathrm{ZrO}_{2}$ is a versatile material due to its properties, such as high chemical inertness, photochemical stability, good wear resistance, and a wide bandgap [4]. $\mathrm{ZrO}_{2}$ has been used in several studies to increase the photocatalytic activity of $\mathrm{TiO}_{2}$ because the coupling of the two semiconductors can achieve a more efficient charge separation, prolong the lifetime of charge carriers, and significantly minimize the recombination probability between the hole and electron [5-6]. The reported value of $\mathrm{ZrO}_{2}$ bandgap energy $\left(\mathrm{E}_{\mathrm{g}}\right)$ is in the range of 3.25 to $5.1 \mathrm{eV}$, limiting the spectrum of photons that can create electron-hole pairs to participate in oxidation or reduction reactions under the UV light [7-8].

A hybrid of $\mathrm{TiO}_{2}$ and $\mathrm{ZrO}_{2}$ has advantageous properties, such as high mechanical strength, high surface area, non-toxicity, corrosion resistance, and photocatalytic activity under sunlight [9]. The combination of $\mathrm{TiO}_{2}$ and $\mathrm{ZrO}_{2}$ inhibits the electron-hole recombination process, which enhances the lifetime of charged carriers, thus improving the photocatalytic activity [10]. Fan et al. conducted a photocatalytic degradation of rhodamine $\mathrm{B}$ using the $\mathrm{TiO}_{2}-\mathrm{ZrO}_{2}$ binary system under visible light irradiation. Results showed a promising photocatalytic activity under the visible-light region [11]. The bandgap of titania-zirconia composite 
was found to be increasing with a decrease in crystallite and particle size [12-13]. The presence of $\mathrm{ZrO}_{2}$ in $\mathrm{TiO}_{2}$ inhibits the anatase-to-rutile phase transformation [14].

Herein, a series of zinc-doped titania was embedded on the zirconia surface by the sol-gel method. Titania was grown on the surface of zirconia to form a composite with higher thermal stability compared to pristine $\mathrm{TiO}_{2}$. Zinc dopant was incorporated into the $\mathrm{TiO}_{2}$ structure in order to shift the absorption ability of the composite to the visible range. Sol-gel route was preferred due to its low cost, easy compositional control, and low processing temperature [15]. Various zinc contents (from 1 to 9\%) and calcination temperatures (from 500 to $900{ }^{\circ} \mathrm{C}$ ) were applied to zirconia supported titania to evaluate the absorption shift and crystal structures.

\section{- EXPERIMENTAL SECTION}

\section{Materials}

Titanium(IV) tetraisopropoxide (TTIP) (97\%, Sigma Aldrich), and zirconia powder $\left(\mathrm{ZrO}_{2}\right)$ (Jiaozuo Huasu) were chosen as titania $\left(\mathrm{TiO}_{2}\right)$ precursor and supporting material, respectively. Zinc chloride $\left(\mathrm{ZnCl}_{2}\right)$ (Merck) was used as a dopant source. Absolute ethanol (PA, Merck) and demineralized water (Jaya Sentosa) were used as solvents.

\section{Instrumentation}

X-ray powder diffractometer (XRD) PANalytical X'Pert PRO MRD ( $\mathrm{Cu}$ Ka radiation $\lambda=1.54 \AA$, $40 \mathrm{kV}$, $30 \mathrm{~mA}$ ) was used to analyze the crystalline structure of composites. Vibrational spectra were measured on a Fourier transform infrared spectrophotometer (FT-IR, Thermo Nicolet Is10). Specular reflectance UV-Vis spectrometer UV 1700 Pharmaspec (SR-UV) was used to analyze the absorption of composites. Scanning Electron Microscope-Energy Dispersive X-Ray Spectrometer (SEM-EDX) FLEXSEM1000 with an accelerating voltage of $10 \mathrm{kV}$ was used to analyze the morphology and elemental composition of synthesized composites.

\section{Procedure}

First, $2.5 \mathrm{~mL}$ of TTIP was diluted into $25 \mathrm{~mL}$ of absolute ethanol under mild stirring. Various amounts of $\mathrm{ZnCl}_{2}$ and $1 \mathrm{~g}$ of $\mathrm{ZrO}_{2}$ were mixed in $25 \mathrm{~mL}$ of demineralized water. The percentage of zinc dopant was fixed at 1,3,5,7, and $9 \%$ to the weight ratio of titanium. The aqueous suspension was then added dropwise into the TTIP solution while being stirred. The mixture was stirred for another $30 \mathrm{~min}$ to maximize the reaction. Subsequently, the suspended solid was separated by centrifugation at $2000 \mathrm{rpm}$ for $1 \mathrm{~h}$. The obtained solid was aged in the open air for $24 \mathrm{~h}$ followed by the drying process in the oven at $80^{\circ} \mathrm{C}$ for another $24 \mathrm{~h}$. Ultimately, the dried solid was calcined under the atmospheric condition at $500{ }^{\circ} \mathrm{C}$ for $4 \mathrm{~h}$ with a ramp temp of $5{ }^{\circ} \mathrm{C} / \mathrm{min}$. Additionally, the composite with $5 \%$ zinc content was calcined further at 700 and $900{ }^{\circ} \mathrm{C}$.

\section{- RESULTS AND DISCUSSION}

The UV-Vis absorption spectra of $\mathrm{Zn}$-doped $\mathrm{TiO}_{2}$ embedded on the surface of $\mathrm{ZrO}_{2}$ together with pure $\mathrm{TiO}_{2}$ as a reference are shown in Fig. 1, and the corresponding calculated bandgaps are summarized in Table 1. The UV-Vis absorption of the composite was measured to demonstrate the doping effect of $\mathrm{Zn}$ in the $\mathrm{TiO}_{2}$ structure. The bandgap energy $\left(\mathrm{E}_{\mathrm{g}}\right)$ value for $\mathrm{TiO}_{2}$ is $3.12 \mathrm{eV}$, while $\mathrm{Zn}$-doped $\mathrm{TiO}_{2}$ on $\mathrm{ZrO}_{2}$ composites range from 3.08 to $2.87 \mathrm{eV}$. The increment of $\mathrm{Zn}$ content shifted the bandgap energy toward a longer wavelength. The bandgap decreased with the increasing of $\mathrm{Zn}$ content until the optimum condition of 5\%, which exhibits the lowest bandgap of $2.87 \mathrm{eV}$. Zinc metal doping

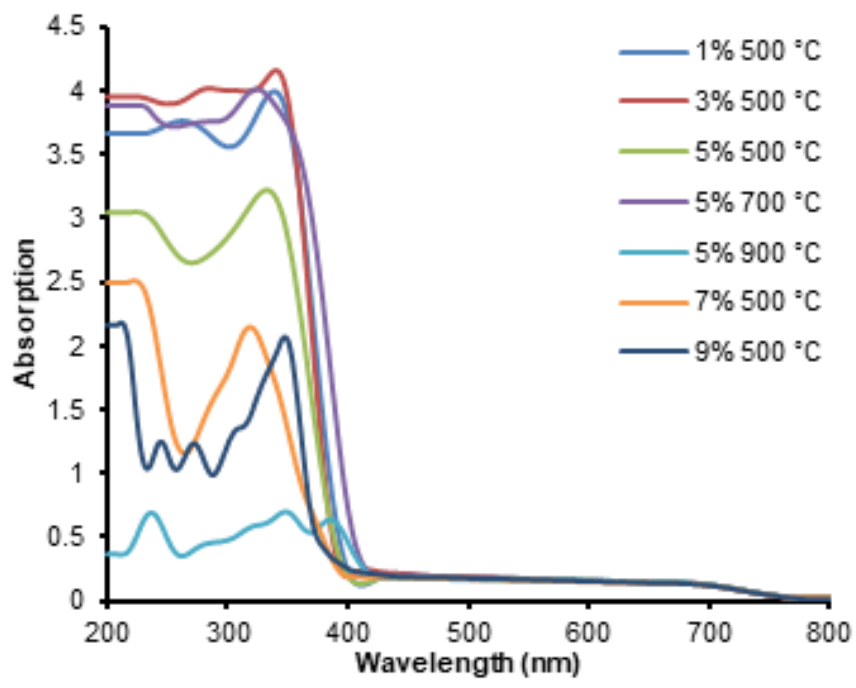

Fig 1. UV-Vis absorption spectra of various $\mathrm{Zn}$-doped $\mathrm{TiO}_{2}$ on $\mathrm{ZrO}_{2}$ composites 
Table 1. Bandgap data of pure $\mathrm{TiO}_{2}$ and composites of $\mathrm{Zn}$-doped $\mathrm{TiO}_{2}$ on $\mathrm{ZrO}_{2}$

\begin{tabular}{lc}
\hline Sample & $\mathrm{E}_{\mathrm{g}}(\mathrm{eV})$ \\
\hline $\mathrm{TiO}_{2} 500{ }^{\circ} \mathrm{C}$ & 3.12 \\
$\mathrm{Zn}$-doped $\mathrm{TiO}_{2}-\mathrm{ZrO}_{2} 1 \% 500{ }^{\circ} \mathrm{C}$ & 3.07 \\
$\mathrm{Zn}$-doped $\mathrm{TiO}_{2}-\mathrm{ZrO}_{2} 3 \% 500^{\circ} \mathrm{C}$ & 2.99 \\
$\mathrm{Zn}$-doped $\mathrm{TiO}_{2}-\mathrm{ZrO}_{2} 5 \% 500{ }^{\circ} \mathrm{C}$ & 2.90 \\
$\mathrm{Zn}$-doped $\mathrm{TiO}_{2}-\mathrm{ZrO}_{2} 5 \% 700{ }^{\circ} \mathrm{C}$ & 2.89 \\
$\mathrm{Zn}$-doped $\mathrm{TiO}_{2}-\mathrm{ZrO}_{2} 5 \% 900^{\circ} \mathrm{C}$ & 2.87 \\
$\mathrm{Zn}$-doped $\mathrm{TiO}_{2}-\mathrm{ZrO}_{2} 7 \% 500{ }^{\circ} \mathrm{C}$ & 2.98 \\
Zn-doped $\mathrm{TiO}_{2}-\mathrm{ZrO}_{2} 9 \% 500{ }^{\circ} \mathrm{C}$ & 3.08 \\
\hline
\end{tabular}

in $\mathrm{TiO}_{2}$ structure introduces new energy levels into the bandgap of $\mathrm{TiO}_{2}$. When zinc is doped into $\mathrm{TiO}_{2}$ lattice, some of the newly occupied molecular orbitals located below the conduction band (CB) of $\mathrm{TiO}_{2}$ are formed. Therefore, this redshift and enhanced light absorption are attributed to the charge transfer from the dopant energy level of $\mathrm{Zn}$ to the $\mathrm{CB}$ of $\mathrm{TiO}_{2}$ or O $2 \mathrm{p}$ to $\mathrm{Zn} 3 \mathrm{~d}$ instead of $\mathrm{Ti} 3 \mathrm{~d}$ [16]. The absorption of $\mathrm{TiO}_{2}-\mathrm{ZrO}_{2}$ composite with $7 \%$ and $9 \%$ of zinc contents returned to the lower wavelength due to the aggregation of $\mathrm{ZnO}$ formed during calcination. The increasing calcination temperature from 500 to $900{ }^{\circ} \mathrm{C}$ decreased the bandgap energy. It was caused by the phase transformation of $\mathrm{TiO}_{2}$ from anatase to rutile. The $\mathrm{E}_{\mathrm{g}}$ of rutile phase $(3.0 \mathrm{eV})$ is lower than that of the anatase crystal phase $(3.2 \mathrm{eV})$. Thus, the bandgap energy of the sample calcined at $900{ }^{\circ} \mathrm{C}$ was lower than samples calcined at 500 and $700{ }^{\circ} \mathrm{C}$.

Fig. 2 shows the surface morphology and corresponding EDX spectra of pure $\mathrm{TiO}_{2}$ and $5 \% \mathrm{Zn}$ doped $\mathrm{TiO}_{2}$ on the $\mathrm{ZrO}_{2}$ composite calcined at $500{ }^{\circ} \mathrm{C}$. The elemental composition of the samples obtained from EDX measurements is given in Table 2. The EDX images of elementals distribution of $\mathrm{Zn}$-doped $\mathrm{TiO}_{2}$ on the $\mathrm{ZrO}_{2}$ composite calcined at $500{ }^{\circ} \mathrm{C}$ are shown in Fig. 3. It can be seen that the undoped $\mathrm{TiO}_{2}$ particle morphology is spherical in general, and $\mathrm{Zn}$-doped $\mathrm{TiO}_{2}$ on the $\mathrm{ZrO}_{2}$ composite looks rougher feature than $\mathrm{TiO}_{2}$. It is clear from the elemental analysis that $0.95 \%$ of the $\mathrm{Zn}$ element was present in the doped samples. In addition,
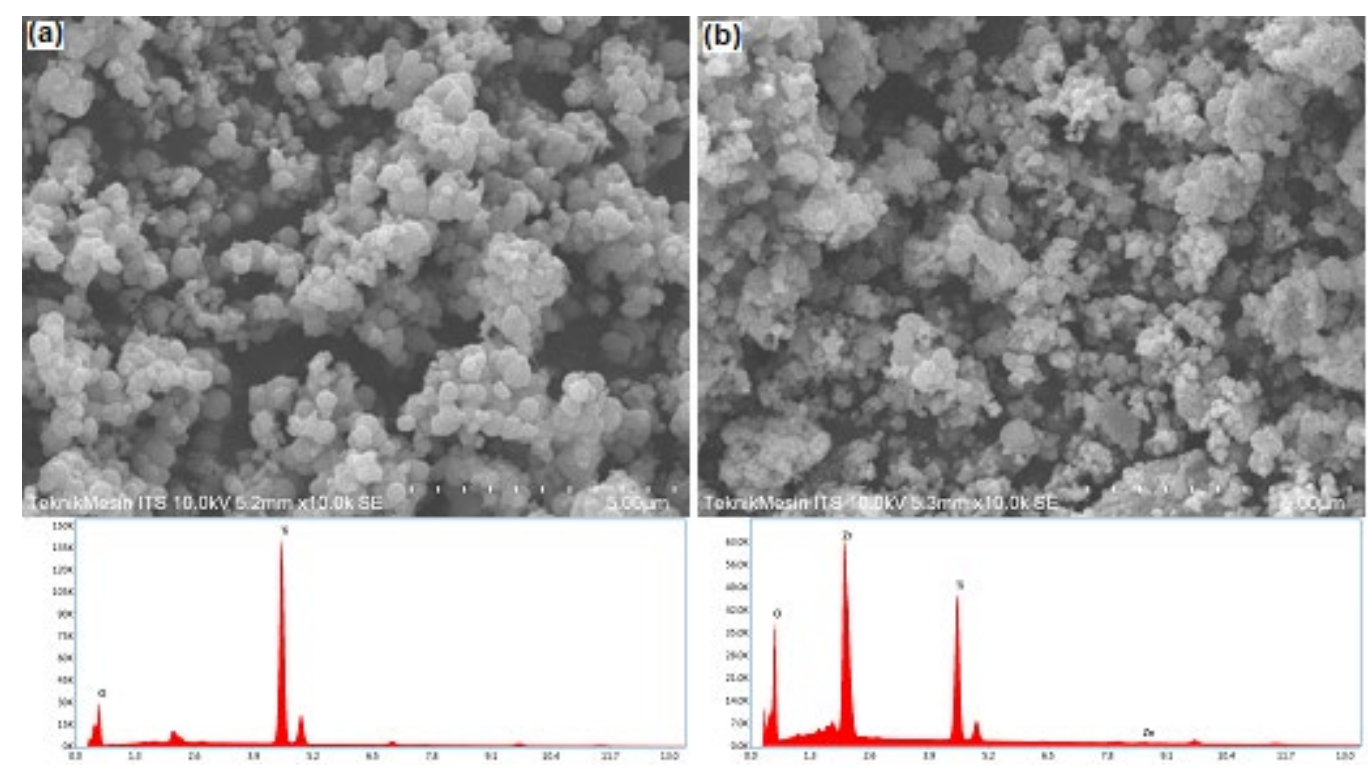

Fig 2. SEM images and EDX spectra of (a) $\mathrm{TiO}_{2}$ and (b) $5 \% \mathrm{Zn}$-doped $\mathrm{TiO}_{2}$ on $\mathrm{ZrO}_{2}$ composite calcined at $500{ }^{\circ} \mathrm{C}$

Table 2. Elemental surface composition of $\mathrm{TiO}_{2}$ and $5 \% \mathrm{Zn}$-doped $\mathrm{TiO}_{2}$ on $\mathrm{ZrO}_{2}$ composite both calcined at $500{ }^{\circ} \mathrm{C}$

\begin{tabular}{lccccc}
\hline \multirow{2}{*}{ Material } & \multicolumn{5}{c}{ \% Mass } \\
\cline { 2 - 6 } & $\mathrm{Zr}$ & $\mathrm{O}$ & $\mathrm{Ti}$ & $\mathrm{Zn}$ & Total \\
\hline $\mathrm{TiO}_{2}$ & - & 36.82 & 63.18 & - & 100 \\
$5 \% \mathrm{Zn}$-doped $\mathrm{TiO}_{2}-\mathrm{ZrO}_{2}$ & 31.16 & 41.51 & 26.39 & 0.95 & 100 \\
\hline
\end{tabular}



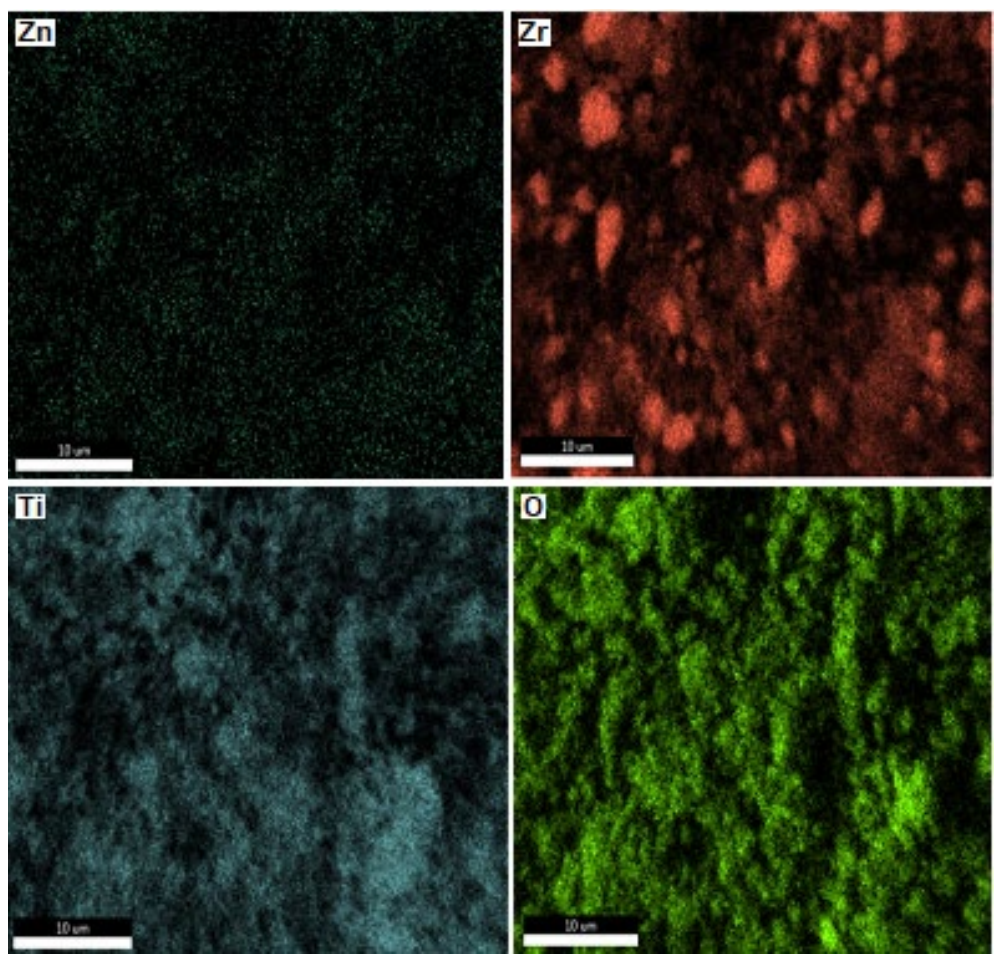

Fig 3. Elemental mapping images of $5 \% \mathrm{Zn}$-doped $\mathrm{TiO}_{2}$ on $\mathrm{ZrO}_{2}$ composite calcined at $500{ }^{\circ} \mathrm{C}$

it can be revealed from the analysis that $\mathrm{Zn}$ had been successfully incorporated on the surface of the $\mathrm{TiO}_{2}-\mathrm{ZrO}_{2}$ composite. EDX spectra and data confirm that there was no impurity in the samples.

XRD patterns of undoped and $\mathrm{Zn}$-doped $\mathrm{TiO}_{2}$ on $\mathrm{ZrO}_{2}$ composites together with pure $\mathrm{TiO}_{2}$ calcined at $500{ }^{\circ} \mathrm{C}$ are shown in Fig. 4 . Zn-doped composite calcined at $500{ }^{\circ} \mathrm{C}$ exists in two main crystalline forms, anatase and monoclinic, and no peak related to the rutile or any other phase is observed. Two main peaks of anatase $\mathrm{TiO}_{2}$ are at $2 \theta$ of $25^{\circ}(101)$ and $48^{\circ}(200)$, which is closely matching with ICDD PDF number: 00-002-0387. On the other hand, XRD peaks of $\mathrm{ZrO}_{2}$ at $2 \theta$ of $28^{\circ}(-111), 31^{\circ}$ (111), and $34^{\circ}(020)$ are often taken as the characteristic peaks of monoclinic, which is closely matching with ICDD PDF number: 01-074-1200. The presence of the dopant was not found in the XRD patterns, which might be due to either the uniform distribution of dopant in $\mathrm{TiO}_{2}$ lattice or the low amount of dopant used [17]. The presence of the $\mathrm{Zn}$ dopant in the composite was confirmed by EDX analysis, as discussed before. All composites exhibited lowerintensity peaks of anatase at $25^{\circ}$ compared to pure $\mathrm{TiO}_{2}$.

The XRD patterns of $5 \% \mathrm{Zn}$-doped $\mathrm{TiO}_{2}$ on $\mathrm{ZrO}_{2}$ composites calcined at different temperatures are presented in Fig. 5. XRD pattern of undoped $\mathrm{TiO}_{2}$ calcined at $500{ }^{\circ} \mathrm{C}$ shows only anatase phase at $2 \theta$ of $25^{\circ}$ (101) and $48^{\circ}(200)$, while the XRD pattern of Zn-doped $\mathrm{TiO}_{2}-\mathrm{ZrO}_{2}$ composite displays a weak anatase peak at $2 \theta$ of $25^{\circ}(101)$ and strong monoclinic peaks at $2 \theta$ of $28^{\circ}$ $(-111)$ and $31^{\circ}(111)$. XRD pattern of $\mathrm{Zn}$-doped $\mathrm{TiO}_{2}-$ $\mathrm{ZrO}_{2}$ calcined at $700{ }^{\circ} \mathrm{C}$ had an emerging rutile peak at $2 \theta$ of $27^{\circ}(110)$ and a diminished anatase peak at $25^{\circ}$ (101). This suggests that there was a phase transformation from anatase to rutile at about $700{ }^{\circ} \mathrm{C}$, which agrees with the previous experiment [18]. The diffraction peaks at $2 \theta=27^{\circ}(110), 36^{\circ}(101), 41^{\circ}(111)$, and $54^{\circ}(211)$ correspond to the rutile phase (ICDD PDF number: 00-004-0551). After calcination at $900{ }^{\circ} \mathrm{C}$, the anatase peak disappeared while the rutile peak became stronger than that at $700{ }^{\circ} \mathrm{C}$. The presence of $\mathrm{ZrO}_{2}$ and $\mathrm{Zn}$ dopant are presumably responsible for inhibiting the transformation of anatase to rutile [14,19-20].

FT-IR spectra of various $\mathrm{Zn}$-doped composites together with pure $\mathrm{TiO}_{2}$ are presented in Fig. 6 . Absorption peaks around 500 and $545 \mathrm{~cm}^{-1}$ can be devoted to stretching vibration of the $\mathrm{Ti}-\mathrm{O}$ bond and 


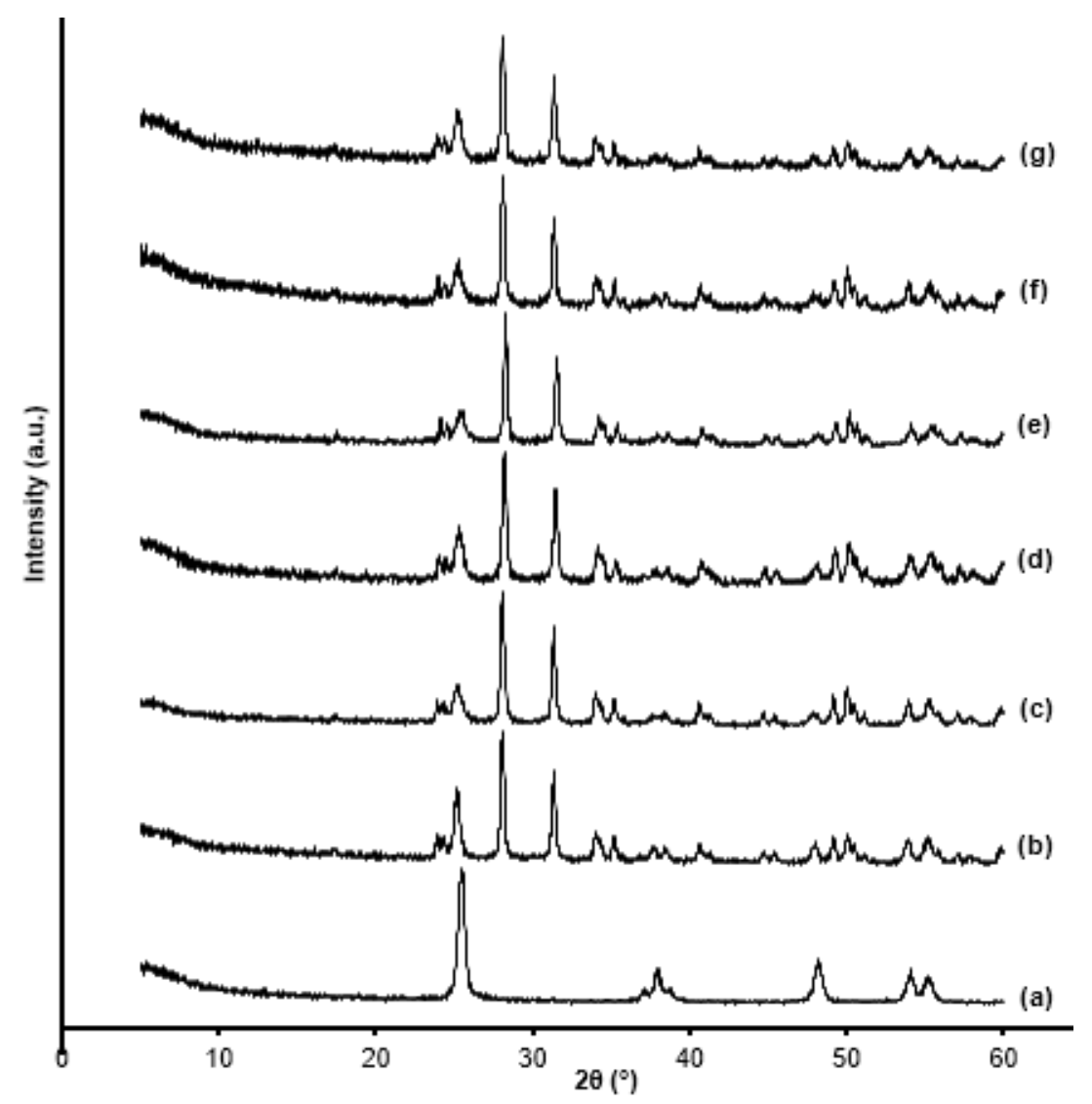

Fig 4. XRD patterns of (a) $\mathrm{TiO}_{2}$, (b) undoped and $\mathrm{Zn}$-doped $\mathrm{TiO}_{2}$ on $\mathrm{ZrO}_{2}$ composites with $\mathrm{Zn}$ content of (c) 1, (d) 3, (e) 5 , (f) $7,(\mathrm{~g}) 9 \%(\mathrm{w} / \mathrm{w})$ calcined at $500{ }^{\circ} \mathrm{C}$

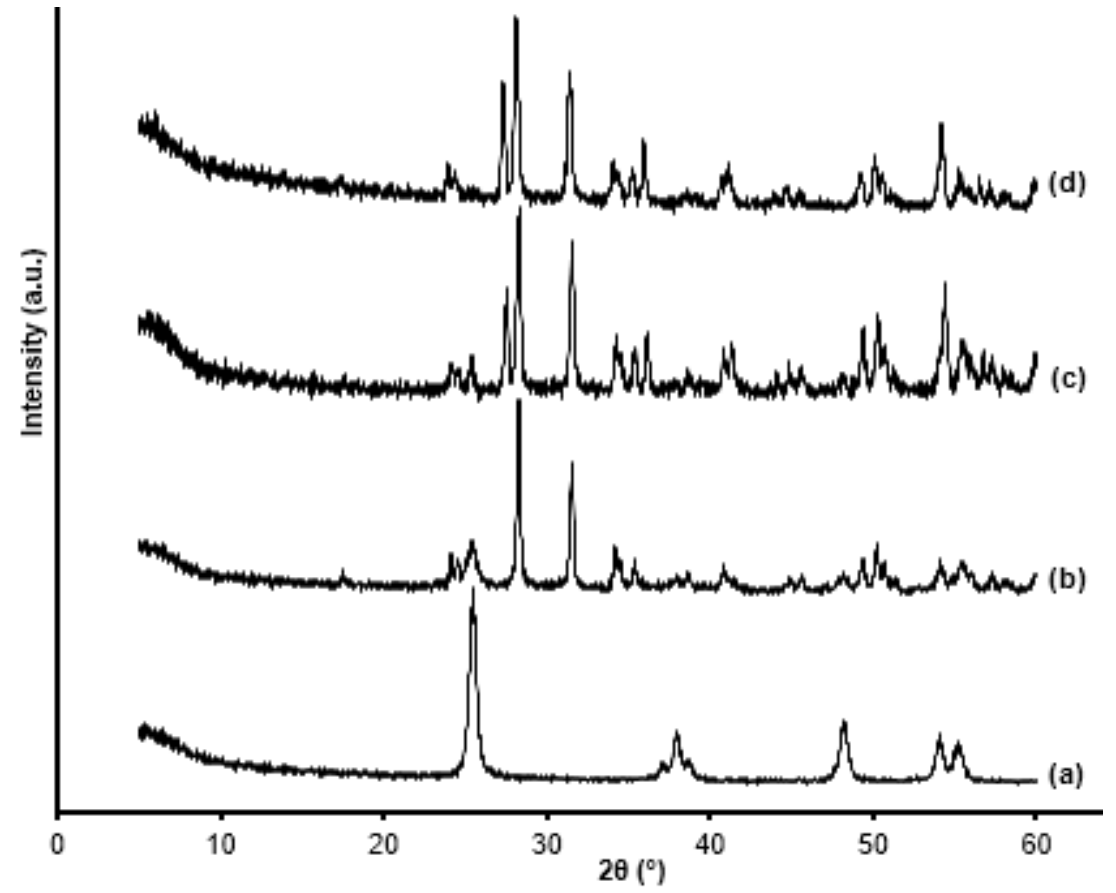

Fig 5. XRD patterns of (a) $\mathrm{TiO}_{2}$ calcined at $500{ }^{\circ} \mathrm{C}, 5 \% \mathrm{Zn}$-doped $\mathrm{TiO}_{2}$ on $\mathrm{ZrO}_{2}$ composites calcined at (b) 500, (c) 700, and (d) $900{ }^{\circ} \mathrm{C}$ 


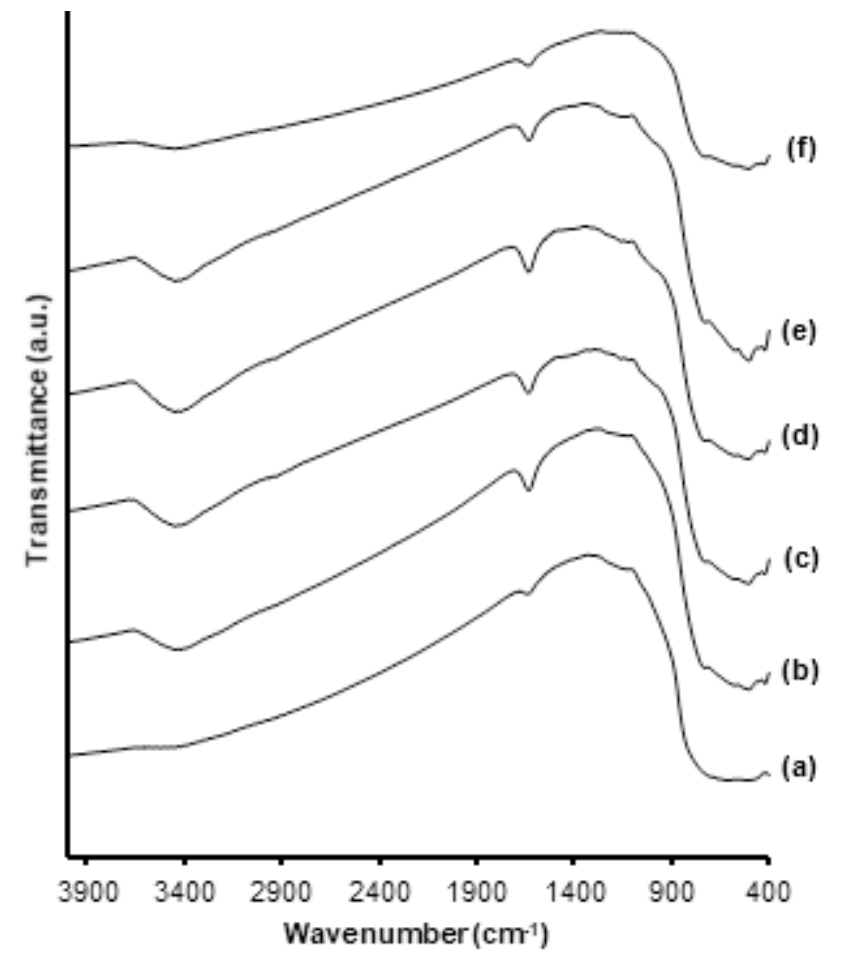

Fig 6. FTIR spectra of (a) $\mathrm{TiO}_{2}$ and $\mathrm{Zn}$-doped $\mathrm{TiO}_{2}$ on $\mathrm{ZrO}_{2}$ composites with $\mathrm{Zn}$ content of (b) 1, (c) 3, (d) 5, (e) 7, (f) $9 \%(w / w)$ calcined at $500{ }^{\circ} \mathrm{C}$

$\mathrm{Zr}-\mathrm{O}$ bond, respectively [21-22]. Peaks around 31003600 and $1632 \mathrm{~cm}^{-1}$ are assigned to stretching and bending vibrations of hydroxyl groups, respectively [23]. The absorption peaks of $\mathrm{Ti}-\mathrm{O}$ and $\mathrm{Zr}-\mathrm{O}$ tended to decrease as the $\mathrm{Zn}$ dopant content increased. It indicates that zinc metal was successfully doped into the $\mathrm{TiO}_{2}$ structure. There was a new peak that appeared around $1200 \mathrm{~cm}^{-1,}$ which may belong to $\mathrm{Zn}-\mathrm{O}-\mathrm{Ti}$ vibration at the substitutional position.

Fig. 7 shows the FTIR spectra of $5 \% \mathrm{Zn}$-doped $\mathrm{TiO}_{2}$ on $\mathrm{ZrO}_{2}$ composites calcined at different temperatures, together with $\mathrm{TiO}_{2}$ calcined at $500{ }^{\circ} \mathrm{C}$ as a reference. After calcination at $700{ }^{\circ} \mathrm{C}$, the $\mathrm{O}-\mathrm{H}$ vibration bands became much weaker than those at $500^{\circ} \mathrm{C}$, indicating the removal of a certain amount of $\mathrm{O}-\mathrm{H}$ groups during calcination. After heat treatment at a temperature of $900{ }^{\circ} \mathrm{C}$, the spectra show further disappearance of $\mathrm{O}-\mathrm{H}$ group peaks, indicating a complete elimination of hydroxy groups. The vibration band of $\mathrm{Zn}-\mathrm{O}-\mathrm{Ti}$ around $1200 \mathrm{~cm}^{-1}$ decreased when the calcination temperatures were increased. It was caused by dopant that sinters at high temperature [24].

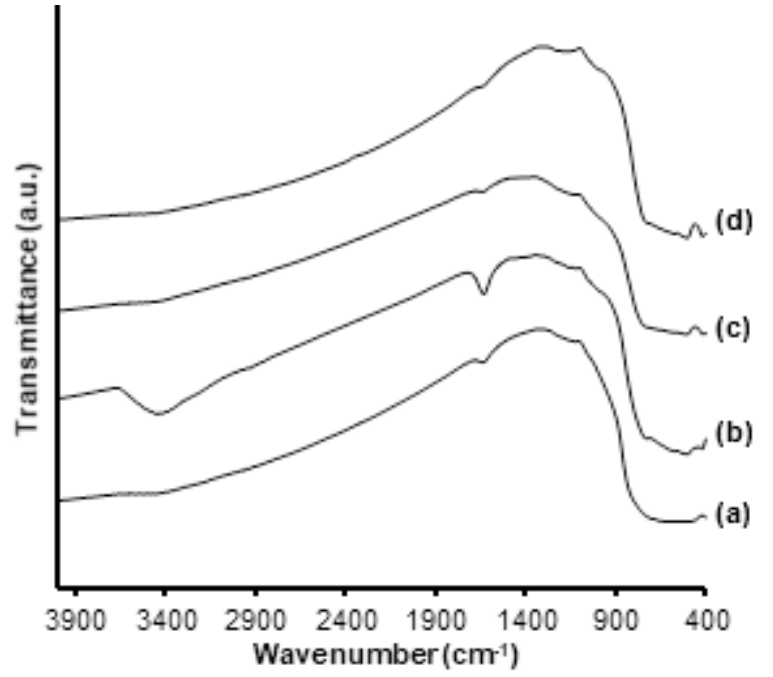

Fig 7. FTIR spectra of (a) $\mathrm{TiO}_{2}$ calcined at $500{ }^{\circ} \mathrm{C}, 5 \%$ $\mathrm{Zn}$-doped $\mathrm{TiO}_{2}$ on $\mathrm{ZrO}_{2}$ composites calcined at (b) 500, (c) 700 , and (d) $900{ }^{\circ} \mathrm{C}$

The visible-light-response of the synthesized composite based on UV-Vis spectral data gives an insight that the composite has potential as a photocatalyst. The zinc dopant shifts the absorption edge of $\mathrm{TiO}_{2}$ to a higher wavelength, thus increasing the photocatalytic activity of $\mathrm{TiO}_{2}$ hypothetically. Embedding $\mathrm{TiO}_{2}$ on the surface of $\mathrm{ZrO}_{2}$ was proven to inhibit the anatase-to-rutile transformation, thus establishing a relatively thermally stable composite compared to $\mathrm{TiO}_{2}$.

\section{- CONCLUSION}

A series of $\mathrm{Zn}$-doped $\mathrm{TiO}_{2}$ embedded on the surface of $\mathrm{ZrO}_{2}$ with various zinc contents were successfully synthesized through the sol-gel method and calcined at different temperatures. Zn doping results in the improvement of photo-response under visible light irradiation. $\mathrm{TiO}_{2}-\mathrm{ZrO}_{2}$ composite with $5 \%$ of zinc content calcined at $900^{\circ} \mathrm{C}$ exhibits the lowest bandgap of $2.87 \mathrm{eV}$ with an absorption edge wavelength of $432.61 \mathrm{~nm}$. The presence of $\mathrm{ZrO}_{2}$ and $\mathrm{Zn}$ inhibits the anatase-to-rutile transformation at 700 and $900{ }^{\circ} \mathrm{C}$ of calcination temperatures. The experimental results demonstrate that doped $\mathrm{TiO}_{2}$ embedded on the $\mathrm{ZrO}_{2}$ surface with optimal $\mathrm{Zn}$ content can be considered as a promising photocatalyst under visible light irradiation. 


\section{- ACKNOWLEDGMENTS}

We would like to express our gratitude to the Faculty of Mathematics, and Natural Sciences Universitas Gadjah Mada for their support on this works through BPPTNBH 2019 Grant (86/J01.1.28/PL.06.02/2019).

\section{- REFERENCES}

[1] Huang, F., Yan, A., and Zhao, H., 2016, "Influences of doping on photocatalytic properties of $\mathrm{TiO}_{2}$ photocatalyst" in Semiconductor Photocatalysis Materials, Mechanisms and Applications, Eds. Cao, W., IntechOpen, Rijeka, Croatia.

[2] Seabra, M.P., Salvado, I.M.M., and Labrincha, J.A., 2011, Pure and (zinc or iron) doped titania powders prepared by sol-gel and used as photocatalyst, Ceram. Int., 37 (8), 3317-3322.

[3] Nair, R.G., Mazumdar, S., Modak, B., Bapat, R., Ayyub, P., and Bhattacharyya, K., 2017, The role of surface $\mathrm{O}$-vacancies in the photocatalytic oxidation of methylene blue by $\mathrm{Zn}$-doped $\mathrm{TiO}_{2}$ : A mechanistic approach, J. Photochem. Photobiol., A, 345, 36-53.

[4] Yao, N.Q., Liu, Z.C., Gu, G.R., and Wu, B.J., 2017, Structural, optical, and electrical properties of $\mathrm{Cu}-$ doped $\mathrm{ZrO}_{2}$ films prepared by magnetron cosputtering, Chin. Phys. B, 26 (10), 106801.

[5] Jiang, B., Zhang, S., Guo, X., Jin, B., and Tian, Y., 2009, Preparation and photocatalytic activity of $\mathrm{CeO}_{2} / \mathrm{TiO}_{2}$ interface composite film, Appl. Surf. Sci., 255 (11), 5975-5978.

[6] Zheng, R., Meng, X., and Tang, F., 2009, Synthesis, characterization and photodegradation study of mixed-phase titania hollow submicrospheres with rough surface, Appl. Surf. Sci., 255 (11), 5989-5994.

[7] Polisetti, S., Deshpande, P.A., and Madras, G., 2011, Photocatalytic activity of combustion synthesized $\mathrm{ZrO}_{2}$ and $\mathrm{ZrO}_{2}-\mathrm{TiO}_{2}$ mixed oxides, Ind. Eng. Chem. Res., 50 (23), 12915-12924.

[8] Králik, B., Chang, E.K., and Louie, S.G., 1998, Structural properties and quasiparticle band structure of zirconia, Phys. Rev. B: Condens. Matter, 57 (12), 7027-7036.

[9] Kubiak, A., Siwińska-Ciesielczyk, K., and Jesionowski, T., 2018, Titania-based hybrid materials with $\mathrm{ZnO}, \mathrm{ZrO}_{2}$ and $\mathrm{MoS}_{2}$ : A review, Materials, 11 (11), 2295.

[10] Zhang, J., Li, L., Zhang, J., Zhang, X., and Zhang, W., 2017, Controllable design of natural gully-like $\mathrm{TiO}_{2}-\mathrm{ZrO}_{2}$ composites and their photocatalytic degradation and hydrogen production by water splitting, New J. Chem., 41 (17), 9113-9122.

[11] Fan, M., Hu, S., Ren, B., Wang, J., and Jing, X., 2013, Synthesis of nanocomposite $\mathrm{TiO}_{2} / \mathrm{ZrO}_{2}$ prepared by different templates and photocatalytic properties for the photodegradation of Rhodamine B, Powder Technol., 235, 27-32.

[12] Gao, B., Lim, T.M., Subagio, D.P., and Lim, T.T., 2010, Zr-doped $\mathrm{TiO}_{2}$ for enhanced photocatalytic degradation of bisphenol A, Appl. Catal., A, 375 (1), 107-115.

[13] Verma, S., Rani, S., Kumar, S., and Khan, M.A.M., 2018, Rietveld refinement, micro-structural, optical and thermal parameters of zirconium titanate composites, Ceram. Int., 44 (2), 1653-1661.

[14] Andita, K.R., Kurniawan, R., and Syoufian, A., 2019, Synthesis and characterization of $\mathrm{Cu}$-doped zirconium titanate as a potential visible-light responsive photocatalyst, Indones. J. Chem., 19 (3), 761-766.

[15] Kong, L., Karatchevtseva, I., Holmes, R., Davis, J., Zhang, Y., and Triani, G., 2016, New synthesis route for lead zirconate titanate powder, Ceram. Int., 42 (6), 6782-6790.

[16] Wang, Q., Yun, G., An, N., Shi, Y., Fan, J., Huang, H., and $\mathrm{Su}, \mathrm{B} ., 2015$, The enhanced photocatalytic activity of $\mathrm{Zn}^{2+}$ doped $\mathrm{TiO}_{2}$ for hydrogen generation under artificial sunlight irradiation prepared by solgel method, J. Sol-Gel Sci. Technol., 73 (2), 341-349.

[17] Sikirman, A., Krishnan, J., and Mohamad, E.N., 2014, Effect of dopant concentration of N, Fe codoped $\mathrm{TiO}_{2}$ on photodegradation of methylene blue under ordinary visible light, Appl. Mech. Mater., 661, 34-38.

[18] Kim, K.H., Park, H., Ahn, J.P., Lee, J.C., and Park, J.K., 2007, HRTEM study of phase transformation from anatase to rutile in nanocrystalline $\mathrm{TiO}_{2}$ particles, Mater. Sci. Forum, 534-536, 65-68. 
[19] Jing, L., Xin, B., Yuan, F., Xue, L., Wang, B., and Fu, H., 2006, Effects of surface oxygen vacancies on photophysical and photochemical processes of $\mathrm{Zn}$ doped $\mathrm{TiO}_{2}$ nanoparticles and their relationships, $J$. Phys. Chem. B, 110 (36), 17860-17865.

[20] Venkatachalam, N., Palanichamy, M., Arabindoo, B., and Murugesan, V., 2007, Enhanced photocatalytic degradation of 4-chlorophenol by $\mathrm{Zr}^{4+}$ doped nano $\mathrm{TiO}_{2}$, J. Mol. Catal. A: Chem., 266 (1-2), 158-165.

[21] Tsiourvas, D., Tsetsekou, A., Arkas, M., Diplas, S., and Mastrogianni, E., 2011, Covalent attachment of a bioactive hyperbranched polymeric layer to titanium surface for the biomimetic growth of calcium phosphates, J. Mater. Sci. - Mater. Med., 22 (1), 85-96.
[22] Tamrakar, R.K., Tiwari, N., Dubey, V., and Upadhyay, K., 2015, Infrared spectroscopy and luminescence spectra of $\mathrm{Yb}^{3+}$ doped $\mathrm{ZrO}_{2}$ nanophosphor, J. Radiat. Res. Appl. Sci., 8 (3), 399403.

[23] Gao, Y., Masuda, Y., Peng, Z., Yonezawa, T., and Koumoto, K., 2003, Room temperature deposition of a $\mathrm{TiO}_{2}$ thin film from aqueous peroxotitanate solution, J. Mater. Chem., 13 (3), 608-613.

[24] Kurniawan, R., Sudiono, S., Trisunaryanti, W., and Syoufian, A., 2019, Synthesis of iron-doped zirconium titanate as a potential visible-light responsive photocatalyst, Indones. J. Chem., 19 (2), 454-460. 